\title{
Development of an Operational Plan for the Liquid Biopsy External Quality Assessment Program in Korea
}

\author{
Sunyoung Ahn¹, Hyun-Ki Kim², Ji Hyun Kim², Woochang Lee², Sail Chun², Wee Gyo Lee³, \\ and Won-Ki Min² \\ ${ }^{1}$ Department of Laboratory Medicine, Kangwon National University School of Medicine, Chuncheon; 2Department of Laboratory \\ Medicine, Asan Medical Center, University of Ulsan College of Medicine, Seoul; ${ }^{3}$ Department of Laboratory Medicine, \\ Ajou University School of Medicine, Suwon, Korea
}

\section{Corresponding author:}

Woochang Lee

Department of Laboratory Medicine, Asan Medical Center, University of Ulsan College of Medicine, 88 Olympic-ro 43gil, Songpa-gu, Seoul 05505, Korea Tel +82-2-3010-4506

Fax +82-2-478-0884

E-mail wlee1@amc.seoul.kr

Received: November 27, 2019

Revised: January 21, 2020

Accepted: March 6, 2020
This is an Open Access article distributed under the terms of the Creative Commons Attribution Non-Commercial License (http://creativecommons.org/licenses/ by-nc/4.0) which permits unrestricted non-commercial use, distribution, and reproduction in any medium, provided the original work is properly cited.
Background: Liquid biopsy is a useful assay for the diagnosis, treatment, and prognosis prediction of solid tumors and its clinical application is expanding. Therefore, the need for developing an External Quality Assessment (EQA) protocol for liquid biopsy is increasing. In this study, we developed and implemented the liquid biopsy EQA program for the epidermal growth factor receptor mutation.

Methods: We validated the feasibility of the protocol using citrate instead of ethylenediaminetetraacetic acid (EDTA). Additionally, we analyzed the homogeneity and stability of the aliquoted quality control (QC) materials. Mutation-positive QC material with four mutations (exon 19 deletion, L858R, T790M, and exon 20 insertion) was used to make two types of QC materials (low and high) and the wild type material was used for the negative controls. If the EQA results showed consensus in more than $80 \%$ of the participating laboratories, the results were reported as acceptable or unacceptable. If not, we reported the results as not graded.

Results: Citrate showed equivalent performance to EDTA. Highly mutated QC material and mutation-negative QC material passed the homogeneity and stability test, but low-level mutant specimens showed inconsistent results. In total, 11 laboratories participated, and all of them reported consistent results except for low-grade mutant samples. Thus, the evaluation results were acceptable except for low mutation QC material.

Conclusions: The applicability of liquid biopsy is expanding. To obtain accurate test results, EQA is indispensable. Here, QC materials for liquid biopsy EQA were produced, distributed, and had its results analyzed. This study could be the foundation for further development of liquid biopsy EQA.

(Lab Med Qual Assur 2020;42:91-96)

Key Words Liquid biopsy, External Quality Assessment, Laboratory proficiency testing, Epidermal growth factor receptor 
서론

액체생검(liquid biopsy)은 고형 장기가 아닌 액상 검체에서 임 상적으로 중요한 정보를 얻는 검사를 포괄적으로 의미하며, 특히 종양 환자의 혈액에서 순환하는 혈중 순환종양핵산(circulating tumor DNA, ctDNA) 또는 혈액 검체 내에서 채집한 순환종양세 포를 이용해 이루어지는 검사를 의미한다. 종양세포들은 ctDNA 를 혈액이나 조직액으로 분비하며, 이 ctDNA를 검사하는 방법은 질병의 조기 진단 및 예후 예측, 재발 여부, 약물의 치료효과 예측 등 여러 분야에 적용 가능하다. 무엇보다 기존의 직접적인 생검방 법에 비해 비침습적으로 필요한 정보를 얻을 수 있다는 장점이 있 어 기술적 진보와 더불어 앞으로 그 적용범위가 확대될 것으로 기 대된다[1]. 또한 기존의 고전적 조직검사가 조직의 일부만을 채취 하여 검사하므로 대상 조직의 이질성(tumoral heterogeneity) 에 의해 검사결과가 달라질 수 있는 반면, 액체생검은 원발 병소와 전이 병소를 모두 포함한 포괄적인 검사결과를 얻을 수 있다. 이러 한 ctDNA의 임상적 활용에 대해 잘 알려진 종양으로는 대장암, 유 방암, 난소암, 간암, 췌장암, 비소세포폐암(non-small-cell lung cancer) 등이 있다[2].

이러한 액체생검과 관련된 검사들 중 대표적인 사례로 폐암 환 자에서 혈중의 epidermal growth factor receptor (EGFR) 유 전자 돌연변이를 검출하는 검사법인 Roche사의 Cobas EGFR Ver2 kit (Roche Diagnostics, Mannheim, Germany)를 들 수 있다. 이 키트는 EGFR을 표적으로 하는 EGFR-tyrosine kinase inhibitor (EGFR-TKI) 약물인 erlotinib, osimertinib의 치료효 과를 예측할 수 있는 동반진단 검사법(companion diagnostics) 으로 몇 년 전 미국 Food and Drug Administration의 승인을 받 았으며[3,4], 한국의 경우 해당 키트가 2018년 5월부터 보험급여 가 적용되면서 조직검사 시행이 어려운 환자들에게 많은 도움이 되고 있다[5]. 특히 EGFR T790M 돌연변이의 검사결과는 EGFRTKI 치료 중 약제 변경을 고려하는 데 있어 매우 중요하다. 그러 므로 액체생검은 정확한 검사결과의 보고가 필수적이며, 공신력 있는 기관에 의한 외부정도관리(external quality assessment [EQA], proficiency testing [PT])가 이루어져야 한다.

액체생검은 혈장에 존재하는 종양세포 유래 핵산 추출과정과 추출한 핵산을 대상으로 한 유전자 돌연변이 검사과정의 두 단계 를 통해 이루어지는데, 종양세포 유래 핵산의 농도가 상대적으로 매우 낮아 핵산 추출 시 혈액 내 백혈구 유래 핵산과의 구별이 어 렵기 때문에 핵산 추출단계 또한 검사의 신뢰도를 결정하는 중요 한 요인이 된다. 따라서 $\mathrm{EQA}$ 프로그램도 핵산 추출단계와 돌연변 이 검사 두 단계를 모두 평가할 수 있도록 고안되어야 한다[6].

국내 임상검사실을 대상으로 하는 외부정도관리는 대한임상
검사정도관리협회를 중심으로 이루어지고 있다. 해당 협회는 외 부정도관리 수행기관에 대한 인증을 관장하는 International Organization for Standardization (ISO) 17043 인증을 획득한 바 있어 외부정도관리 수행기관으로서의 위상에 대해 국제적으로 인정받았다[7]. 그러나 액체생검에 대하여는 아직까지 EQA 프로 그램에 대한 공인된 운영방안이 확립되어 있지 않다. 대한임상검 사정도관리협회는 2017년부터 액체생검 신빙도조사사업 프로그 램을 운영하기 시작하였으며, 저자들은 해당 프로그램 운영자로서 액체생검 정도관리 검체 제조를 포함한 액체생검 신빙도조사 프로 그램 운영 업무를 수행하여 왔다. 이에 저자들은 본 경험을 바탕으 로 실험적 검증을 통한 액체생검 외부정도관리 검체 제조지침을 확정하고, 액체생검 신빙도조사사업 운영방안을 제시하며, 시행된 액체생검 신빙도조사사업의 결과를 분석하여 보고함과 동시에 평 가에 관한 지침을 확정하려 한다.

\section{재료 및 방법}

\section{1. 액체생검 외부정도관리물질 제조방식에 대한 실험적 검증 및 방안 수립}

본 연구에서는 먼저 대량 검체 제조에 용이한 citrate 항응 고제 사용 가능 여부를 결정하기 위해 항응고제 평가를 실시하 였다. 종양 발병 과거력이 없는 건강한 정상인의 혈액을 각각 citrate tube, ethylenediaminetetraacetic acid (EDTA) tube 로 채혈한 후 원심분리기로 $1,500 \mathrm{~g}, 8$ 분간 분리하여 획득한 supernatant 혈장에 각각 EGFR exon 19 deletion과 T790M 돌연변이를 가지는 세포주(HCC827, H1975) 유래 DNA를 주입 (spiking)하여 만든 검체로 혈장 EGFR 검사를 다음과 같이 시 행하였다. 먼저 생산한 검체 $2 \mathrm{~mL}$ 를 Roche cfDNA sample preparation kit (Roche Diagnostics)를 이용해 DNA 분리 및 DNA 추출과정을 시행한 후, 증폭을 거쳐 얻어진 산물을 Cobas EGFR test kit (Roche Diagnostics)를 사용해 Cobas z 480 analyzer (Roche Diagnostics)로 돌연변이 유무를 판별하였다.

또한 외부정도관리 양성 검체에 주입되어야 하는 DNA의 양을 결정하기 위해 Roche Cobas EGFR Ver2 kit (Roche Diagnostics)의 제품설명서(product insert)에 제시된 limit of detection (https://www.accessdata.fda.gov/cdrh_docs/ pdf15/P150047c.pdf)를 근거로 하여 필요한 DNA의 양을 계 산하였고, 이에 기반하여 Horizon Discovery사의 상용 cfDNA Reference Standard (Horizon Discovery Group, Cambridge, $\mathrm{UK}$ )를 폐기 대상 fresh frozen plasma (FFP)에 주입하여 외부정 도관리 검체를 제조하였다. 본 연구에 사용된 Horizon Discovery Group사의 상용 cfDNA는 human cell line에서 유래한 핵산으 
로서 평균 160 base pair 크기이며 8종류의 돌연변이를 포함하고 있다. 대량의 정도관리 검체 제조에 사용한 FFP의 경우 본원 혈액 은행에서 폐기 예정인 FFP를 획득하여 원심분리기에 3,400 rpm, 10 분간 분리하여 사용하였다. FFP와 Horizon Discovery cfDNA 를 이용하여 만든 정도관리 검체들은 $-80^{\circ} \mathrm{C}$ 에서 보관하였으며, 추후 정해진 일정에 따라 균질성 및 안정성 검증이 시행되었다.

\section{2. 생산된 액체생검 정도관리물질의 균질성 및 안정성}

ISO guide 35에 근거하여 액체생검 외부정도관리 검체의 균질 성 및 안정성을 평가하였다[8]. 냉장 후 24시간, 48시간, 72 시간 이후의 안정성 및 냉동 검체의 1 주, 2 주 후의 안정성을 평가하였 으며 하루 두 검체씩 무작위로 추출하여 3 일에 걸쳐 균질성을 평 가하였다(Fig. 1).

\section{3. 결과분석 및 통계}

ISO 13528 의 지침 및 대한임상검사정도관리협회의 정성검 사 보고원칙에 따라 각 돌연변이 종류 및 농도별로 $80 \%$ 이상의 consensus를 이룬 경우에는 consensus와 일치하는 결과를 보 고한 기관에 대해 acceptable을, 불일치한 결과를 보고한 기관 에 대하여는 unacceptable을 부여하였다[9]. 만약 $80 \%$ 미만 의 consensus를 보일 때는 not graded로 결과를 정하였다. 통 계분석에는 IBM SPSS Statistics for Windows ver. 24.0 (IBM Corp., Armonk, NY, USA), Excel 2016 (Microsoft Corp., Redmond, WA, USA) 및 MedCalc Statistical Software ver. 16.8.4 (MedCalc Software Ltd., Ostend, Belgium)를 사용하 였다.

\section{결과}

\section{1. 액체생검 외부정도관리검사에 항응고제가 미치는 영향}

Citrate tube로 채혈한 검체 및 EDTA tube로 채혈한 검체 모 두에서 유사한 ctDNA 농도 및 검사결과를 보여 citrate 항응고제 를 이용해 채혈한 검체가 EDTA 항응고제 검체와 동등한 수준의 수행능을 보임을 확인하였다(Table 1).

\section{2. 액체생검 외부정도관리물질의 균질성 및 안정성 검증}

액체생검 외부정도관리검체의 균질성 및 안정성 판정기준을 다 음과 같이 정하였다. 고농도 양성 검체의 경우 exon 19 deletion, exon 20 insertion, T790M, L858R의 네 가지 돌연변이가 모두 양성이 나와야 하고, 야생형(wild type) 검체의 경우 상기의 네 가 지 돌연변이에 대해 모두 음성이어야 한다. 저농도 양성 검체는 미 리 목표치를 설정하지 않고 참가기관이 보고한 결과의 일치도 여 부에 근거하여 허용기준을 설정하였다. Fig. 1 과 같은 계획에 따라 균질성 및 안정성을 검증하였으며, 균질성 검증결과는 Table 2, 안정성 검증결과는 Table 3과 같았다. 안정성 평가결과 고농도 검 체의 경우 네 가지 돌연변이가 모든 검체에서 양성으로 검출되었 으며, 야생형 검체의 경우 네 가지 돌연변이가 모든 검체에서 음성 으로 나타났다. 균질성 평가를 위해 추출한 모든 고농도 양성 검체 에서도 네 가지 돌연변이가 모두 양성으로 나타났으며, 야생형 검 체에 대해서는 모두 돌연변이 음성이 확인되었다. 따라서 고농도 양성 검체와 야생형 검체에 대하여는 균질성과 안정성이 모두 검 증되었다. 한편, 저농도 양성 검체의 경우 일관성 있는 결과를 보 이지 않았다. 균질성 검증에서는 exon 19 deletion 돌연변이 검 체를 제외한 다른 돌연변이 검체들에서 모두 음성결과가 검출되었 고, 안정성 검증에서는 L858R, exon 20 insertion 돌연변이에서 음성결과가 나타나, 균질성 검증과 안정성 검증을 모두 통과하지 못하였다. 따라서 본 사업에서는 저농도 양성 검체에 대해서는 신 빙도 판정을 내리지 아니하였다.

Table 1. Anticoagulation effects on EGFR mutation using the Roche Cobas EGFR kit

\begin{tabular}{clccc}
\hline $\begin{array}{c}\text { Sample } \\
\text { ID }\end{array}$ & $\begin{array}{c}\text { Anti- } \\
\text { coagulant }\end{array}$ & $\begin{array}{c}\text { ctDNA } \\
\text { size } \\
\text { (base } \\
\text { pair) }\end{array}$ & $\begin{array}{c}\text { ctDNA } \\
\text { concen- } \\
\text { tration } \\
\text { (ng/ } \mu \mathrm{L})\end{array}$ & $\begin{array}{c}\text { Mutation } \\
\text { detected } \\
\text { (SQI) }\end{array}$ \\
\hline 1 & EDTA & 178 & 0.972 & Ex19Del (19.45) \\
\hline 1 & Citrate & 181 & 0.972 & Ex19Del (20.45) \\
\hline 2 & EDTA & 182 & 0.891 & T790M (12.67) \\
\hline 2 & Citrate & 180 & 0.891 & T790M (13.60) \\
\hline
\end{tabular}

The instrument was from the following company: Roche Cobas EGFR kit (Roche Diagnostics, Mannheim, Germany).

Abbreviations: EGFR, epidermal growth factor receptor; ctDNA, circulating tumor DNA; SQI, Semi-Quantitative Index; EDTA, ethylenediaminetetraacetic acid.

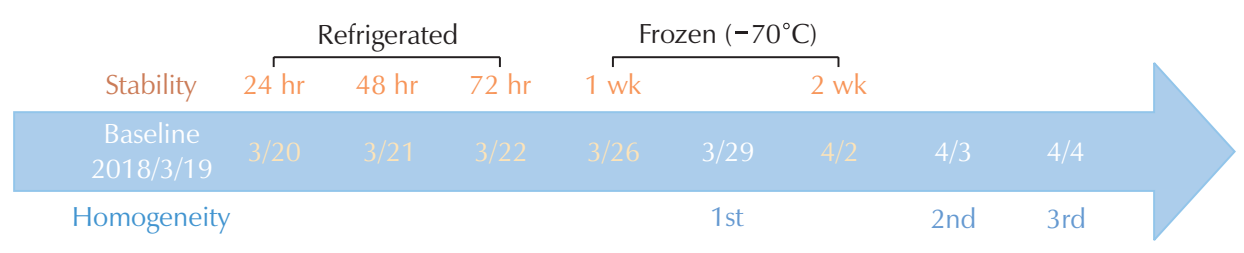

Fig. 1. Scheme of stability and homogeneity tests for the reference material used for the epidermal growth factor receptor plasma external quality assess ment through this study. 
Table 2. Homogeneity test results of the epidermal growth factor receptor plasma external quality assessment reference materials produced

\begin{tabular}{|c|c|c|c|c|c|c|c|}
\hline \multirow{2}{*}{$\begin{array}{l}\text { Specimen: mutation } \\
\text { concentration }\end{array}$} & \multirow{2}{*}{ Baseline } & \multicolumn{2}{|c|}{$2018 / 3 / 29$} & \multicolumn{2}{|c|}{$2018 / 4 / 3$} & \multicolumn{2}{|c|}{$2018 / 4 / 4$} \\
\hline & & Sample 1 & Sample 2 & Sample 3 & Sample 4 & Sample 5 & Sample 6 \\
\hline Ex19Del_high & Pos & Pos & Pos & Pos & Pos & Pos & Pos \\
\hline L858R_high & Pos & Pos & Pos & Pos & Pos & Pos & Pos \\
\hline T790M_high & Pos & Pos & Pos & Pos & Pos & Pos & Pos \\
\hline Ex20Ins_high & Pos & Pos & Pos & Pos & Pos & Pos & Pos \\
\hline Ex19Del_low & Pos & Pos & Pos & Pos & Pos & Pos & Pos \\
\hline L858R_low & Pos & Pos & Pos & Neg & Pos & Pos & Neg \\
\hline T790M_low & Pos & Pos & Pos & Neg & Pos & Pos & Neg \\
\hline Ex20Ins_low & Neg & Pos & Pos & $\mathrm{Neg}$ & Pos & Pos & Neg \\
\hline Ex19Del_Neg & Neg & Neg & Neg & Neg & Neg & $\mathrm{Neg}$ & Neg \\
\hline L858R_Neg & Neg & Neg & Neg & Neg & Neg & Neg & Neg \\
\hline T790M_Neg & Neg & Neg & Neg & Neg & Neg & Neg & Neg \\
\hline Ex20Ins_Neg & $\mathrm{Neg}$ & Neg & Neg & Neg & Neg & $\mathrm{Neg}$ & Neg \\
\hline
\end{tabular}

Abbreviations: Pos, positive; Neg, negative.

Table 3. Stability test results of the epidermal growth factor receptor plasma external quality assessment reference materials produced

\begin{tabular}{|c|c|c|c|c|c|c|}
\hline $\begin{array}{l}\text { Specimen: mutation } \\
\text { concentration }\end{array}$ & Baseline & $24 \mathrm{hr}$ & $48 \mathrm{hr}$ & $72 \mathrm{hr}$ & $1 \mathrm{wk}$ & $2 w k$ \\
\hline Ex19Del_high & Pos & Pos & Pos & Pos & Pos & Pos \\
\hline L858R_high & Pos & Pos & Pos & Pos & Pos & Pos \\
\hline T790M_high & Pos & Pos & Pos & Pos & Pos & Pos \\
\hline Ex20Ins_high & Pos & Pos & Pos & Pos & Pos & Pos \\
\hline Ex19Del_low & Pos & Pos & Pos & Pos & Pos & Pos \\
\hline L858R_low & Pos & Pos & Pos & Pos & Pos & Neg \\
\hline T790M_low & Pos & Pos & Pos & Pos & Pos & Pos \\
\hline Ex20Ins_low & Neg & Neg & Neg & Neg & Neg & Neg \\
\hline Ex19Del_neg & Neg & Neg & Neg & Neg & Neg & Neg \\
\hline L858R_neg & Neg & Neg & Neg & Neg & Neg & Neg \\
\hline T790M_neg & Neg & Neg & Neg & Neg & Neg & Neg \\
\hline Ex20Ins_neg & Neg & Neg & Neg & Neg & Neg & Neg \\
\hline
\end{tabular}

Abbreviations: Pos, positive; Neg, negative.

\section{3. 본 신빙도조사 프로그램의 참여기관 및 사업결과}

고농도, 저농도, 야생형의 세 가지 검체를 총 11 개 기관에 발송 하였으며, 신청한 기관 모두가 결과를 회신하였다. 이번 평가에 참 여한 11 개 기관의 검사결과는 Table 4에 요약하였다. 참여한 11 개 기관이 모두 동일한 검사장비와 시약을 사용하여 11 개 참여기 관 전체를 하나의 동료집단(peer group)으로 간주하고 평가하였 다. 검사결과 모든 검사실에서 야생형 검체들에서는 돌연변이가
검출되지 않았고, 높은 농도의 돌연변이 양성 검체들에서는 예상 했던 돌연변이들이 검출되었다고 보고하였다. 따라서 야생형 검 체와 고농도 돌연변이 검체에 대하여는 모든 기관에 acceptable 을 부여하였다. 반면, 저농도 돌연변이 양성 검체에서는 기 서술한 바와 같이 exon 19 deletion을 제외한 나머지 L858R, T790M, exon 20 insertion의 경우에서 검체의 균질성 및 안정성이 확보 되었다고 간주할 수 없어, 해당 검체에 대해서는 not graded로 판 
Table 4. Full test results of the epidermal growth factor receptor plasma external quality assessment conducted by 11 laboratories

\begin{tabular}{|c|c|c|c|c|c|c|c|c|c|c|c|c|}
\hline \multirow{3}{*}{$\begin{array}{l}\text { Lab } \\
\text { no. }\end{array}$} & \multicolumn{12}{|c|}{ Mutation type } \\
\hline & \multicolumn{3}{|c|}{ Exon 19 deletion } & \multicolumn{3}{|c|}{ L858R } & \multicolumn{3}{|c|}{ T790M } & \multicolumn{3}{|c|}{ Exon 20 insertion } \\
\hline & $\begin{array}{c}\text { High } \\
\text { con } \\
\text { sample }\end{array}$ & $\begin{array}{l}\text { Low con } \\
\text { sample }\end{array}$ & $\begin{array}{l}\text { Nega- } \\
\text { tive }\end{array}$ & $\begin{array}{c}\text { High } \\
\text { con } \\
\text { sample }\end{array}$ & $\begin{array}{c}\text { Low } \\
\text { con } \\
\text { sample }\end{array}$ & $\begin{array}{l}\text { Nega- } \\
\text { tive }\end{array}$ & $\begin{array}{c}\text { High } \\
\text { con } \\
\text { sample }\end{array}$ & $\begin{array}{c}\text { Low } \\
\text { con } \\
\text { sample }\end{array}$ & $\begin{array}{l}\text { Nega- } \\
\text { tive }\end{array}$ & $\begin{array}{l}\text { High } \\
\text { con } \\
\text { sample }\end{array}$ & $\begin{array}{c}\text { Low } \\
\text { con } \\
\text { sample }\end{array}$ & $\begin{array}{l}\text { Nega- } \\
\text { tive }\end{array}$ \\
\hline 1 & Pos & Pos & Neg & Pos & Pos & Neg & Pos & Pos & Neg & Pos & Pos & Neg \\
\hline 2 & Pos & Pos & Neg & Pos & Pos & Neg & Pos & Pos & Neg & Pos & Neg & Neg \\
\hline 3 & Pos & Pos & Neg & Pos & Pos & Neg & Pos & Pos & Neg & Pos & Neg & Neg \\
\hline 4 & Pos & Pos & Neg & Pos & Pos & Neg & Pos & Pos & Neg & Pos & Pos & Neg \\
\hline 5 & Pos & Pos & Neg & Pos & Pos & Neg & Pos & Neg & Neg & Pos & $\mathrm{Neg}$ & Neg \\
\hline 6 & Pos & Pos & Neg & Pos & Pos & Neg & Pos & Pos & Neg & Pos & Neg & Neg \\
\hline 7 & Pos & Pos & Neg & Pos & Pos & Neg & Pos & Pos & Neg & Pos & Pos & Neg \\
\hline 8 & Pos & Pos & Neg & Pos & Pos & Neg & Pos & $\mathrm{Neg}$ & $\mathrm{Neg}$ & Pos & Neg & Neg \\
\hline 9 & Pos & Pos & $\mathrm{Neg}$ & Pos & Pos & Neg & Pos & Pos & Neg & Pos & Neg & $\mathrm{Neg}$ \\
\hline 10 & Pos & Pos & Neg & Pos & Pos & Neg & Pos & Pos & $\mathrm{Neg}$ & Pos & Neg & Neg \\
\hline 11 & Pos & Pos & $\mathrm{Neg}$ & Pos & Pos & $\mathrm{Neg}$ & Pos & Pos & $\mathrm{Neg}$ & Pos & $\mathrm{Neg}$ & $\mathrm{Neg}$ \\
\hline
\end{tabular}

Abbreviations: Con, concentration; Pos, positive; Neg, negative.

정하였다.

\section{고찰}

최근 들어 임상검사실에 도입되기 시작한 액체생검은 종양 환 자의 치료 및 관리에 중요한 정보를 제공함으로써 새롭게 각광 받는 분야이며, 따라서 해당 검사의 정확도 검증을 위한 외부정 도관리 체계 확립의 필요성이 대두되고 있다. 현재 유럽의 경우 The European Molecular Genetics Quality Network를 통 해 EGFR 및 RAS 유전자에 대하여 ctDNA를 분주한 혈장 검체를 이용한 외부정도관리사업을 수행하고 있다. 한편, 미국의 대표적 인 외부정도관리기관인 College of American Pathologists에 서도 2018년도부터 cfDNA 검사에 대한 외부정도관리를 시행하 기 시작하였다. 국내의 경우 2017년 plasma cell-free DNA에서 의 EGFR 돌연변이에 대한 pilot EQA가 시행된 바 있으나, 공신력 이 공식적으로 입증된 $\mathrm{EQA}$ 시행기관의 평가가 아니었으며, 해당 $\mathrm{EQA}$ 운영에 사용한 검체 또한 균질성 및 안정성 검증이 시행되지 않은 것이었다[10].

외부정도관리를 위해서는 최대한 실제 검사의 상황과 유사한 조건의 검체를 제공하는 것이 권고되며, 따라서 액체생검의 경우 검체에 미량으로 존재하는 핵산의 추출과정이 검사 수행능에 결정 적인 영향을 미치므로 핵산 추출 및 검사단계를 모두 평가할 수 있 는 혈장 기반 검체를 사용하는 것이 바람직하다. 또한 검사에 필요
한 혈장의 양과 외부정도관리 참여 검사실의 수를 고려하여 충분 한 양의 검체를 확보해야 하므로 검체 채취 시 사용하는 항응고제 에 따른 검사 수행능에 대해서도 평가가 이루어져야 한다. 본 연구 에서는 일반적인 액체생검에 이용되는 EDTA 항응고제와 대량 검 체 수집에 흔히 이용되는 citrate 항응고제의 수행능을 비교 평가 하여 citrate 항응고제를 액체생검 수행 시 사용할 수 있음을 확인 하였다.

일반적으로 외부정도관리 프로그램의 합격판정기준(acceptance criteria)과 이와 관련된 통계학적 분석은 사전 설계되어 명 시되어야 한다. 명확한 정답이 있는 경우 양성 혹은 음성으로 사전 에 정할 수 있으나 사전 평가에서 일관성 있는 결과를 보이지 않 는 경우 not graded로 분류하여 판정하지 않는 것이 바람직하다. 또한 외부정도관리는 외부정도관리 검체가 각 참여기관에 배포된 후 검사가 이루어지는데, 이때 검체 운반 및 보관조건에 따라 검체 의 변성이 일어날 수 있으며, 이로 인해 검사결과에 유의한 영향 을 미칠 수 있으므로 우선 검체의 안정성이 확보되어야 한다. 그리 고 각 참여 검사실에 배포되는 검체가 동일한 성상을 가져야 각 검 사실의 수행능에 대한 적절한 평가가 가능하므로 외부정도관리 검 체 배포 전에 검체의 균질성을 확인하는 과정이 필요하다. 본 연구 에서는 한 달 미만의 기간에 검체 제조 및 배포가 이루어지는 점을 고려하여 수개월 이상의 장기 안정성 평가는 실시하지 않았고 균 질성 및 단기 안정성 평가만을 수행하였다. 평가결과 고농도 돌연 변이 및 야생형 검체의 경우 모든 검체에서 일관된 결과를 얻었으 
나, 저농도 돌연변이 검체에서는 안정성과 균질성 모두 불일치하 는 결과들을 보여 검사실 수행능 평가에 사용하기에는 적절하지 않은 것으로(not graded) 판단하였다.

결론적으로, 본 연구에서는 real-time polymerase chain reaction 기반 혈장 EGFR 검사법(액체생검)에 대한 외부정도관 리사업을 포괄적으로 진행하여 정도관리 검체 제조부터 분석결과 판정까지의 일련의 과정을 성공적으로 수행하였다. 본 연구를 통 해 향후 임상적 적용범위가 확장될 것으로 예상되는 액체생검의 질적 수준을 높이는데 필수적인 외부정도관리사업 시행의 기준이 될 수 있는 자료를 제공하였다고 생각되며, 본 연구 자료가 추후
정도관리를 통한 액체생검 분야의 지속적인 발전을 위해 기여할 수 있을 것으로 기대된다.

\section{감사의 글}

이 연구는 대한임상검사정도관리협회의 2018년 학술연구비 지 원으로 수행되었다(과제번호: 2018-05). ISO 17043 기반 액체생 검 외부정도관리사업에 참여하여 주신 모든 검사실의 의료진께 감 사드린다.

\section{REFERENCES}

1. Arneth B. Update on the types and usage of liquid biopsies in the clinical setting: a systematic review. BMC Cancer 2018;18:527.

2. Karachaliou N, Sosa AE, Molina MA, Centelles Ruiz M, Rosell R. Possible application of circulating free tumor DNA in non-small cell lung cancer patients. J Thorac Dis 2017;9(Suppl 13):S1364-72.

3. Lynch TJ, Bell DW, Sordella R, Gurubhagavatula S, Okimoto RA, Brannigan BW, et al. Activating mutations in the epidermal growth factor receptor underlying responsiveness of non-small-cell lung cancer to gefitinib. N Engl J Med 2004;350:2129-39.

4. Koc A, Goksel T, Komurcuoglu B, Kaya OO, Ozyilmaz B, Gursoy P, et al. Liquid biopsy for EGFR mutations in nonsmall cell lung cancer cases by RT-PCR. Eur Respir J 2018;52(Suppl 62):PA1757.

5. Han AL, Kim HR, Choi KH, Hwang KE, Zhu M, Huang Y, et al. Comparison of cobas EGFR mutation test v2 and PANAMutyper-R-EGFR for detection and semi-quantification of epidermal growth factor receptor mutations in plasma and pleural effusion supernatant. Ann Lab Med 2019;39:478-87.

6. Paweletz CP, Janne PA. Monitoring cancer through the blood. Cancer 2014;120:3859-61.

7. International Organization for Standardization. ISO/IEC 17043:2010: conformity assessment: general requirements for proficiency testing. Geneva: International Organization for Standardization, 2010.

8. International Organization for Standardization. ISO guide 35:2006: reference materials: general and statistical principles for certification. Geneva: International Organization for Standardization, 2006.

9. International Organization for Standardization. ISO 13528:2015: statistical methods for use in proficiency testing by interlaboratory comparison. Geneva: International Organization for Standardization, 2016.

10. Kim Y, Shin S, Lee KA. A comparative study for detection of EGFR mutations in plasma cell-free DNA in Korean clinical diagnostic laboratories. Biomed Res Int 2018;2018:7392419. 